\title{
Cultural context of nursing in the field of outpatient healthcare in Serbia
}

\author{
Kulturowy kontekst pielęgniarstwa w dziedzinie ambulatoryjnej opieki nad chorymi w Serbii
}

\author{
Sanja Stanisavljević, Divna Kekuś
}

Academy for Applied Studies Belgrade, Department of Higher Medical School /Akademia Studiów Zawodowych w Belgradzie, Wyższa Szkoła Medyczna

\author{
CORRESPONDING AUTHOR: \\ Sanja Stanisavljević \\ Academy for Applied Studies Belgrade, Serbia \\ Branislava Nušića 18/14, 26.220 Kovin, Serbija \\ tel. $+381641296375 ;+38113745847$ \\ e-mail: stanisavljevicsanja@gmail.rs
}

STRESZCZENIE

Słowa kluczowe:

\section{ABSTRACT}

\section{KULTUROWY KONTEKST PIELEGNIARSTWA W DZIEDZINIE AMBULATORYJNEJ OPIEKI NAD CHORYMI W SERBII}

Wstęp. Współczesna mapa świata charakteryzuje istnienie pluralistycznych i wielokulturowych społeczeństw powstałych w wyniku zwiększonej mobilności obywateli i procesu globalizacji. Różnorodność kulturowa realizuje swoje implikacje we wszystkich aspektach funkcjonowania społecznego i w znacznym stopniu poprzez system opieki zdrowotnej. Przyjmując koncepcję choroby jako konstruktu społecznego, międzykulturowość staje się przewodnią zasadą edukacji i praktycznych działań pracowników służby zdrowia na wszystkich poziomach. Charakter działalności pielęgniarki w placówkach podstawowej opieki zdrowotnej odgrywa kluczową rolę we wdrażaniu zasad międzykulturowych w praktyce klinicznej z tendencją systemu opieki zdrowotnej do większej otwartości i wrażliwości na specyfikę istniejącej sytuacji społecznej i uwarunkowane kulturowo potrzeby zdrowotne użytkowników.

Cel. Analiza teoretycznego i praktycznego fundamentu wielowymiarowego i różnorodnego podejścia do opieki zdrowotnej.

Wyniki. Dyskurs na temat kulturowego kontekstu opieki pielęgniarskiej w dziedzinie opieki ambulatoryjnej w Serbii opiera się na aksjomatycznym założeniu, że choroba jest konstruktem kulturowym i że perspektywa socjologiczna i antropologiczna może zmienić praktykę kliniczną. Praca przedstawia analizę podstawowych cech kulturowych jako dynamicznych czynników zdrowia i choroby, dodatkowo zasady, elementy i znaczenie oceny kulturowej pacjentów w praktyce pielęgniarskiej; pokazuje różnice w pozycji pacjentów w koncepcji Parsonsa i współczesną koncepcję postmodernistycznego podejścia do pacjenta. Kontekst kulturowy pielęgniarstwa w Serbii został przeanalizowany przez pryzmat „5d Modelu Kulturowego" dr Geerta Hofstede, z prezentacją i interpretacją jego podstawowych wymiarów.

Wnioski. System opieki zdrowotnej w Serbii stoi przed wyzwaniami reformy, wprowadzając aspekt społeczno-kulturowy w tworzeniu polityki podstawowej opieki zdrowotnej w świetle współczesnych wielokulturowych tendencji społecznych. W celu zapewnienia wysokiej jakości opieki zdrowotnej, konieczne jest, aby zrozumieć, jak społeczeństwo postrzega zdrowie i chorobę oraz czynniki kulturowe, które leżą u podstaw zachowań jednostek. Jeśli opieka zdrowotna nie opiera się na wartościach kulturowych, niemożliwe jest osiągnięcie celu terapeutycznego, a zapewniona opieka zdrowotna będzie niekompletna i nieudana. Plan leczenia i opieki nad pacjentem musi być indywidualny, całościowy i kulturowo odpowiedni.

kulturowy kontekst, pielęgniarstwo, model Hofstede, opieka ambulatoryjna

\section{CULTURAL CONTEXT OF NURSING IN THE FIELD OF OUTPATIENT HEALTHCARE IN SERBIA}

Introduction. Modern world map characterizes existence of pluralistic and multicultural societies formed as a result of increased citizens' mobility and globalization process. Cultural diversity realizes its implications in all the aspects of social functioning and in significant share through the system of healthcare. Accepting the concept of illness as a social construct, intercultural attitudes become leading principle of education and practice of healthcare workers at every level. By the nature of their profession, nurses in the primary healthcare institutions acquire key role in the process of implementation of inter-cultural principles in clinical practice, with the aim for the healthcare system to become more open and more sensitive to specific social occurrences and culturally driven healthcare need of its users.

Aim. The expected contribution of the work is oriented towards the possibility of theoretical and practical foundation of multidimensional and multi-perspective approach to healthcare.

Discussion. The discourse of the cultural context of nursing in the field of outpatient healthcare in Serbia is based on the axiomatic assumption that illness is a social construct and that sociological and anthropological perspective can change the clinical practice. The work comprises basic cultural factors as a dynamic factor of health and illness, principles, elements and significance of cultural assessment of the patient in nursing practice; presents the differences in patient's position within the Parsons concept and contemporary concept of post-modern approach to the patient. Cultural concept of nursing in Serbia has been analyzed through the prism of "5D Cultural model" by Dr. Geert Hofsted with presentation and interpretation of its basic dimensions.

Conclusions. Healthcare system in Serbia is facing challenges of reforms - the introduction of socio-cultural aspect in creating of 
primary healthcare policy in the spirit of modern multicultural social tendencies. Aiming to provide quality healthcare it is necessary to understand how a society acknowledges the terms of health and illness and which cultural aspects lies in the base of individual's behavior. If one healthcare is not founded upon cultural values then it is impossible to achieve its therapeutic goal, it will be incomplete and unsuccessful. The treatment plan and patient's care must be individual, holistic and culturally appropriate.

Key words: cultural context, nursing, Hofsted model, outpatient, healthcare

\section{INTRODUCTION}

Modern world map characterizes existence of pluralistic and multicultural societies formed as a result of increased citizens' mobility and globalization process. Cultural diversity realizes its implications in all the aspects of social functioning and in significant share through the system of healthcare.

Due to the nature of its functioning, institutions of the healthcare system are taking an important role in promotion and in practical application of intercultural competencies. The work of public healthcare professionals which is based on the promotion of the health, development and realization of prevention programs with basic outline in specifics of social communities, demands developed intercultural sensitivity. Thus interculturalism is becoming the leading principal in education of healthcare professionals at all levels, especially at primary healthcare. For that cause, in recent decades there have been questioning and adjustment of public healthcare curriculum with present social values and implementation of intercultural principles in current education system [1].

\section{Culture as dynamic factor of health and illness}

Defining the term culture as "...the sum of distinctive spiritual, material, intellectual and emotional patterns of one society or group of people, along with their art, literature, life stile, way of social life, value system, tradition and beliefs" Organization for Education, science and culture of the United Nations [2] urges us to think on differences, multiple meanings and multidimensionality of cultural differences in modern society [3]. Cultural diversity or pluralism denotes the existence of different cultural communities and groups within one society $[4,5]$.

Culture defines many aspects of human life, and in this sense health is also defined not only by biological and ecological factors but by cultural postulates $[6,7]$. The health behaviour of an individual, attitude towards treatment and care for the patient, the perception of illness, the ways of accepting innovations are all characteristics which vary depending on cultural features and are interlaced with culture [5].

Cultural factors which are related to health and illness of an individual, as researches are showing, are: social gradient, family and marital patterns, gender roles and responsibilities, sexual behaviour, preventive forms of health behaviour, demographic and social policy, general healthcare regulations, profession, healthcare habits of the population, the use of psychoactive substances, spare time habits, strategies and therapies for self-healing etc. [7].
Cultural characteristics should be perceived as dynamic factor of health and illness. The condition for providing quality healthcare is the understanding of the population in experiencing and responding to health and illness, and mapping the cultural factors which initiates their health behaviour. If the actions in providing healthcare are not based on cultural values it is impossible to achieve positive healthcare outcome, and the healthcare provided will be unsatisfactory $[5,8,9]$.

\section{Cultural assessment of the patient}

In recent decades it is the clinical practice which insists on individual and holistic approach in planning of care and treatment of patients. Cultural assessment has an important role when it comes to achieving positive treatment outcome.

Cultural assessment of the patients requires gathering of the following data: demographical data, health behaviour (understanding of health and disease, beliefs, customs, habits and prejudices concerning the health, changes in the environment, work activities ect.), method of preserving health and healthcare, alternative and traditional treatment methods, use of health resources and institutions, health beliefs and practices related to giving birth, upbringing and caring for children, traditional practices related to dying patients and their posthumous treatment.

The International Council of Nurses (ICN), American Nursing Academy (ANA) and Transcultural Nursing Association (TNA) have issued a Handbook with aim to create the worldwide nursing practice postulates for providing holistic and cultural adequate healthcare. The Handbook suggests the application of the following nursing practice principles $[10,5]$ :

- Social justice and equality

- Critical perspective

- Cultural awareness and care

- Culture-based healthcare system and organizations

- Supporting and encouraging patients

- Multicultural work staff

- Culture-based patients care in education

- Intercultural communication and leadership

- Development of the inter and transcultural policies

- Evidence-based practice and research

\section{Parsons concept of illness - illness as a cultural construct}

The concept of "sick role" in medical sociology was introduced by Talcott Parsons, 1951. The theoretic significance of this concept is in the change in interpersonal relation doctor-patient from "strictly therapeutic into a relationship defined by a social-supervisory mechanism" [11]. 
Parsons highlights the social perspective of illness: "the person is ill when it behaves as ill person" [12]. Socio-cultural and political context in great deal defines, not only the perception and interpretation of signs and symptoms of a disease of an individual, yet the healthcare strategy and social functioning and social status of an ill person. By taking the role of an ill person, an individual also takes a series of new social, cultural and institutionalized expectations. Parsons defines illness as a limiting factor for social functioning.

In English language there are three distinct words defining this condition: disease, illness and sickness which meanings are interpreted within the observed context [13-16].

- The term "illness" is used to show the emotional state caused by changes in body functions of the patient and consequences that are occurring due to the disease; It is the reflection of a personal experience of pain and disease.

- The term "disease" is used in cases when the stress is on the existence of pathological physical/organic damage and it involves the procedure of medical classification.

- The term "sickness" refers to social position of the person with a disease. An individual is taking the "sick role" and acquires "the legitimate social identity of a sick person".

\section{Geert Hofstede's "5D cultural model"}

The appearance of "health transition" faces the modern society with changes in the structure of morbidity of general population, within which acute infectious diseases suppress chronic-degenerative diseases. Considering the etiological and risk factors in the light of the genesis of these diseases, social and healthcare public slowly abandon the Parsons concept of "sick role", and insist on personal responsibility for ones own health and does not free the sick person of ones social roles.

At the same time, in order to sustainable development, the healthcare system is absorbing the features of economic model of functioning. Healthcare services are being determined and limited in order to be cost-effective, and healthcare activity is transformed into narrow areas of expertise and thus corrupting the holistic approach and collapsing the interpersonal relationship of a patient and healthcare professional $[17,11]$.

Considering the influence of cultural factors on the planning, managing and functioning processes of work organisations and institutions Dr Geert Hofstede, during the period of 1967-1973 with his co-workers, conducted a research involving 116000 people from 120 countries. The study has shown that every evident difference in functioning and organisation are based on cultural differences of employees, considering that the organisational structure, education, working procedures and regulations were almost the same. In his theory Hofstede advocates the necessity of understanding the characteristics of the users of individual services, highlighting the importance of their psychological, sociological and cultural characteristics [18].
The " $5 \mathrm{D}$ cultural model" analyses the following basic dimensions of behaviour and attitudes of members of social groups which can be related to their cultural characteristics [19]:

- Power Distance (PDI) - This dimension represents the degree of inequality in society. In Serbia PDI is high, almost 86. People are accepting the hierarchical order, institutions inequality is prominent. In the health care system, there is still a paternalistic approach of health workers towards the patient.

- Individualism (IDV) - represents the degree of integration of an individual into community. In individualistic cultures the individual cares only about his own interest, while in collectivistic cultures the "we" way of thinking if dominant. In cultures with higher degree of individualism there is a higher respect for the personality of an individual, his engagement, privacy and attitude. According to Hofstede's model Serbia with the index of 25 is considered a "collectivistic" society. Preference and trust are put in family. Alternative and traditional forms of treatment, are accepted and maintained despite conservative therapy.

- Masculinity (MAS) - the features of "male culture" are: requisite for proving, aggression, materialism, competitiveness, and the importance of individual achievements. The "female culture" is characterized by cooperation and care for the weak. Serbia, with the score of 43 is considered a relatively "female society". There is a strive for consensus. Conflict is being dealt with via compromise and negotiation.

- Uncertainty Avoidance Index (UAI) - the assessment of risk level that members of society feel in changeable circumstances. Serbia, with the score of 92 represents a country with very high UAI. It is being insisted on formalization, standardization and establishing hierarchy. There is resistance towards changes. A high degree of aggression and anxiety is present and a low level of tolerance and acceptance of difference.

- Long Term Orientation (LTO) - it refers to material values of a society. There are no data in this category concerning Serbia.

Belonging to different cultural environments causes specific health behaviour of health care system participants. At the same time, cultural and cognitive distance disables quality communication between the participants of health care system and consequently it leads to the discontent of the both provider and recipient of health care services [20,21].

Very few researches in the field of healthcare outcomes related to cultural competency of healthcare professionals show increase in patients cooperation and devotion, higher rate of satisfaction of the family members with healthcare services, a rise of the level of responsibility and satisfaction of the patients if present $[22,23]$. At the same time the lacking of it leads to: inadequate informing or misunderstanding, failure to assess healthcare needs, insufficient engagement of users of healthcare services in the decision making process due to low healthcare literacy [24]. 


\section{CONCLUSIONS}

Healthcare system in Serbia is facing challenges of reforms - the introduction of socio-cultural aspect in creating of primary healthcare policy in the spirit of modern multicultural social tendencies. Aiming to provide quality healthcare it is necessary to understand how a society acknowledges the terms of health and illness and which cultural aspects lies in the base of individual's behaviour. If healthcare is not based upon cultural values then it is impossible to achieve its therapeutic goal, it will be incomplete and unsuccessful. The treatment plan and patient's care must be individual, holistic and culturally appropriate.

Nurses in the primary healthcare institutions acquire key role in the process of implementation of inter-cultural principles in clinical practice, with the aim for the healthcare system to become more open and more sensitive to specific social occurrences and culturally driven healthcare needs of its users.

\section{REFERENCES}

1. Stanisavljević $S$, Kekuš $D$. Teacher of nursing care in the process of multicultural education - role and competence. In: Matijević M, Majkihar M, Pejović D,editors. Proceedings of the 5 th International Scientific Conference on career development for teaching, practice and research in nursing "Developing a focus for nursing through better understanding and implementation of safety, productivity and quality improvement". Beograd, Srbija: Udruženje medicinskih sestara-tehničara Kliničkog centra Srbije "Sestrinstvo"; 2011. p.123-128. Available from: https:// docplayer.net/39177181-Razvoj-fokusa-za-sestrinstvo-kroz-bolje-razumevanjei-implementaciju-bezbednosti-produktivnosti-i-unapredena-kvaliteta-zbornikpredavanja.html (29.05.2019)

2. UNESCO. Guidlelines on Intercultural Education. Education Sector UNESCO, CLD29366, Paris, 2006.

3. Petrović D, Jokić T. (ed.). Interkulturalno obrazovanje u Srbiji - Regulativni okvir, stanje i mogućnosti za razvoj. Beograd: Centar za obrazovne politike; 2016.

4. Žegarac N, Kišjuhas A, Koprivica I. Pojmovnik kulturno kompetentne prakse. Novi Sad: Pokrajinski zavod za socijalnu zaštitu; 2016.

5. Değer V.B. Transcultural Nursing. Intech0pen, Turkey. 2018. Available from: http:// dx.doi.org/10.5772/intechopen.74990 (12.05.2019)

6. Tortumoğlu $G$. Examples of transcultural nursing and cultural care models. Cumhuriyet University Nursing School Journal. 2004; 8(2):47-57.

7. Bolsoy N, Sevil Ü. Health-disease and culture interaction. Atatürk University Nursing School Journal. 2006; 9(3):78-87.

8. Hotun Şahin N, Onat Bayram G, AvcI D. Responsive approach to cultures: Transcultural nursing. Journal of Nursing Education and Research. 2009; 6 (1):2-7.

9. Serrant-Green L. Transcultural nursing education: A view from within. Nurse Education Today. 2001; 21(8):670-678.

10. Douglas MK. Standards of practice for culturally competent nursing care. Journal of Transcultural Nursing. 2011; 22(4):317-333.

11. Staničić Ž. Re(de)konstrukcija Parsonsovog koncepta uloge bolesnika u postmodernom društvu. Rev. soc. Polit. 2007; 14 (3-4): 313-326.

12. Parsons T, Shils, E, Naegele KD, Pitts JR. Teorije o društvu. Prva knjiga. Beograd: Vuk Karadžić; 1969.

13. Bellaby P. What is genuine sickness? The relation between work-discipline and the sick role in a pottery factory. Sociology of Health and IIIness. 1990; 12(1):47-68.

14. Radley A. Making sense of illness. The social psychology of health and disease. London: SAGE Publications; 1998.

15. Field D. The Social definition of illness. In: Tuckett, D. (ed.), An introduction to medical sociology. London and New York: Tavistock Publications; 1976.

16. Berger PL., Luckmann T. Socijalna konstrukcija zbilje. Zagreb: Naprijed; 1992.

17. Kaminski J. Nursing through the Lens of Culture: A multiple gaze. University of British Columbia, Curriculum Studies, Faculty of Education; 2006.

18. Hofstede G. Culture's Consequences: Comparing Values, Behaviors, Institutions and Organizations Across Nations. 2nd ed. Thousand Oaks: SAGE Publications; 2001.
19. Mirosavljević M, Milovanović M. Osnovne kulturološke dimenzije po Geert Hofstede - u, na primjeru Republike Srbije. Aktuelnosti - časopis za društvena pitanja. 2012; 19: 73-84. Available from:: www.researchgate.net/publication/320265253 (18.05.2019)

20. Kleinman A, Eisenberg L, Good JB. Culture, Illness, and Care: Clinical Lessons From Anthropologic and Cross-Cultural Research. FOCUS the journal of lifelong learning in psychiatry. 2006; 4(1): 140-149.

21. Rupčić D. Bolest u procjepu biologije i kulture - Postmoderno shvaćanje bolesti kao biokulturne pojave. Filozofska istraživanja. 2016; 36 (3): 421-438.

22. Lie D, Lee-Rey E, Gomez A, et al. Does Cultural Competency Training of Health Professional Improve Patient Outcomes? A Systematic Review and Proposed Algorithm for Future Research. J. Gen Intern Medicine. 2010; 26(3): 317-25.

23. Beach MC, Price E, Gary T, et al. Cultural Competency: A Systematic Review of Health Care Provider Educational Interventions. Med Care 2005; 43(4): 356-73.

24. Internacional Council of Nursing. Closing the gap: Increasing access and equity. Geneva: ICN; 2011.

Manuscript received: 03.06.2019

Manuscript accepted: 03.07.2019 